Journal of Clinical Investigation

Iol. 41, No. 6, 1962

\title{
ERYTHROCYTE METABOLISM. V. LEVELS OF GLYCOLYTIC ENZYMES AND REGULATION OF GLYCOLYSIS *
}

\author{
By ROBERT G. CHAPMAN, $\dagger$ M. A. HENNESSEY, A. M. WALTERSDORPH, \\ F. M. HUENNEKENS AND BEVERLY W. GABRIO \\ (From the Departments of Biochemistry and Medicine, University of Washington, and \\ the King County Blood Bank, Seattle, Wash.)
}

(Submitted for publication December 26, 1961 ; accepted February 5, 1962)

In contrast to many other cell types in which a variety of metabolic pathways may contribute to energy production, the human erythrocyte derives its energy almost exclusively from the breakdown of glucose to lactate via the glycolytic sequence. Lactate can arise also from glucose by an alternate route, namely the hexose monophosphate shunt and the pentose cycle, but this latter pathway is relatively inoperative in the erythrocyte under normal conditions, owing to the unexplained preferential conversion of glucose-6-phosphate to fructose-6-phosphate, rather than to 6-phosphogluconate. The red cell, therefore, offers a unique opportunity to correlate physiological function, or malfunction, with enzymatic activity, since the number of metabolic pathways, fortunately, is somewhat restricted.

In the present investigation a detailed study has been undertaken to define the optimal conditions for the conversion of glucose to lactate in the intact erythrocyte and in hemolysates. In addition, levels of the individual glycolytic enzymes have been determined and this information has been used to discuss regulatory mechanisms of glycolysis in the erythrocyte.

\section{EXPERIMENTAL}

Materials. Human blood was collected in acid citrate dextrose (ACD preservative, National Institutes of Health, Formula A). Only fresh blood was used throughout these experiments. Semicarbazide was obtained from

\footnotetext{
* This work was supported by research grants from the Office of the Surgeon General, Department of the Army (Contract DA-49-007-MD-508) and from the National Heart Institute, United States Public Health Service (H-4614). A preliminary report on this work has appeared (1).

$\dagger$ Postdoctoral Fellow of the National Heart Institute. Present address: Department of Medicine, University of Colorado, Denver, Colo.
}

Eastman Organic Chemicals; DPN, 1 TPN, DPNH, TPNH, sodium pyruvate, fructose-1,6-diphosphate, fructose-6-phosphate, and glucose-6-phosphate from Sigma Chemical Company; ADP and ATP from Pabst Laboratories; phosphoenolpyruvate, 3-phosphoglycerate, 2-phosphoglycerate, lactic dehydrogenase, pyruvic kinase, 3phosphoglyceraldehyde dehydrogenase, $\alpha$-glycerophosphate dehydrogenase, triose isomerase, enolase, aldolase, and glucose-6-phosphate dehydrogenase from C. F. Boehringer and Sons; 2,3-diphosphoglycerate, and dehydrated firefly tails from Schwarz BioResearch, Inc.; glucose oxidase from Worthington Biochemical Corporation; and DL-3-phosphoglyceraldehyde as the diethyl acetal monobarium salt from Nutritional Biochemicals Corporation [conversion to the free aldehyde was accomplished by boiling for 3 minutes in an aqueous suspension of Dowex$50\left(\mathrm{H}^{+}\right)$]. Lithium DL-lactate was prepared according to the method of Barker (2) from commercial lactic acid (Mallinckrodt Chemical Co.).

Methods. The $\mathrm{pH}$ of the reaction mixtures was measured with a glass, constant temperature, blood electrode (Beckman Co.). Hemoglobin was measured by the procedure of Evelyn and Malloy (3). Lactate and glucose were determined enzymatically with lactic dehydrogenase (4) and glucose oxidase (5), respectively. Phosphate was measured by a method described previously (6). ATP was assayed by the bioluminescent reaction of firefly extracts containing luciferin and luciferase (7, 8) with the use of the G. K. Turner fluorometer. ADP was measured with the coupled reaction, pyruvic kinaselactic dehydrogenase (9). Fructose was determined by the method of Roe (10), fructose-6-phosphate by a modification (11) of the method of Dische and Borenfreund (12), and glucose-6-phosphate dehydrogenase by the procedure of Kornberg and Horecker (13).

Measurement of glycolytic enzymes. Hemolysates were prepared by freezing and thawing (three times) an aqueous suspension of erythrocytes, previously washed once with 1 vol of $0.15 \mathrm{M} \mathrm{KCl}$. Amounts of hemolysate containing 0.005 to $0.50 \mathrm{mg}$ of hemoglobin were used for measuring the activities of the individual glycolytic enzymes. All enzyme assays were performed in $0.05 \mathrm{M}$

1 The following abbreviations are used in this report: DPN and TPN, di- and triphosphopyridine nucleotide; DPNH, TPNH, reduced DPN and TPN; $A D P$ and ATP, adenosine di- and triphosphate; and $P_{1}$, inorganic phosphate. 


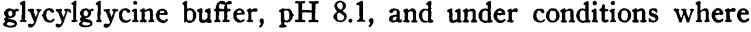
activity was proportional to enzyme concentration and time. Enzyme activities are expressed as micromoles of substrate reacting per hour per milliliter of red cells. Except where otherwise noted, assays were carried out spectrophotometrically, using coupled systems linked to the oxidation and reduction of pyridine nucleotides; conditions were arranged whereby the enzyme to be measured was rate limiting. Spectrophotometric measurements were made with a Beckman DU or DK-1 spectrophotometer at $25^{\circ} \mathrm{C}$ in a $1 \mathrm{ml}$ cuvet of $1 \mathrm{~cm}$ optical path. Absorbancy at $340 \mathrm{~m} \mu$ was followed at convenient intervals (30 seconds or 1 minute) over a 5 - to 10 -minute period. A millimolar extinction coefficient of 6.22 at 340 $\mathrm{m} \mu$ was used for DPNH and TPNH.

Specifically, the following assay systems were employed for the determination of enzyme activities. In general, previously described methods were modified and adapted to the measurement of glycolytic enzymes in the hemolysate. The concentrations of the reactants are given for each assay.

Hexokinase was assayed in a system coupled with TPNdependent glucose-6-phosphate dehydrogenase. The increase in absorbancy at $340 \mathrm{~m} \mu$, indicative of $\mathrm{TPNH}$ formation, was correlated with the utilization of substrate in the primary reaction catalyzed by hexokinase. The assay mixture contained glucose, $5 \times 10^{-3} \mathrm{M}$; ATP, $2 \times$ $10^{-3} \mathrm{M} ; \mathrm{MgCl}_{2}, 7 \times 10^{-3} \mathrm{M}$; TPN, $1 \times 10^{-4} \mathrm{M}$; and glucose-6-phosphate dehydrogenase, $0.002 \mathrm{mg}$. It should be noted that considerably higher values are obtained when hexokinase is assayed by measuring the ADP produced in the primary reaction as a limiting reactant in the pyruvic kinase-lactic dehydrogenase reaction. In this case the "ATP-ase" activity of hexokinase contributes to the measurement.

Phosphoglucose isomerase activity was determined by several methods: 1) in a system containing glucose-6phosphate $\left(2 \times 10^{-8} \mathrm{M}\right), \mathrm{MgCl}_{2}\left(3 \times 10^{-3} \mathrm{M}\right)$, and ATP $\left(2 \times 10^{-3} \mathrm{M}\right)$ for the two-step conversion of glucose-6phosphate to fructose-1,6-diphosphate, utilizing endogenous phosphofructokinase to catalyze the second step; the production of ADP was measured in the pyruvic kinaselactic dehydrogenase reaction $(9) ; 2)$ in a system containing glucose-6-phosphate $\left(2 \times 10^{-3} \mathrm{M}\right)$ and enzyme source incubated at $25^{\circ} \mathrm{C}$ for 30 minutes; fructose-6phosphate was measured chemically $(11,12)$; and 3$)$ in a system utilizing the reaction, fructose-6-phosphate $\rightarrow$ glucose-6-phosphate, coupled with the TPN-dependent glucose-6-phosphate dehydrogenase reaction, according to the method of Srere, Cooper, Tabachnik and Racker (14). The assay mixture contained fructose-6-phosphate, $2 \times 10^{-3} \mathrm{M} ; \mathrm{MgCl}_{2}, 2 \times 10^{-2} \mathrm{M} ; \mathrm{TPN}, 2 \times 10^{-4} \mathrm{M}$; and glucose-6-phosphate dehydrogenase, $0.005 \mathrm{mg}$.

Phosphofructokinase was assayed in a system coupled with aldolase, triose isomerase and DPNH-dependent $\alpha$-glycerophosphate dehydrogenase (15). The assay mixture contained fructose- 6 -phosphate, $7 \times 10^{-4} \mathrm{M}$; ATP, $2 \times 10^{-3} \mathrm{M} ; \mathrm{MgCl}_{2}, 1 \times 10^{-3} \mathrm{M}$; DPNH, $1 \times 10^{-4} \mathrm{M}$; cysteine, $7 \times 10^{-3} \mathrm{M}$; aldolase, $0.20 \mathrm{mg}$; triose isomerase,
$0.01 \mathrm{mg}$; and $\alpha$-glycerophosphate dehydrogenase, $0.01 \mathrm{mg}$.

For the measurement of aldolase activity, adaptations of two methods were used: 1) The procedure of $\mathrm{Wu}$ and Racker (16) whereby the reaction is coupled with triose isomerase and DPNH-dependent $\alpha$-glycerophosphate dehydrogenase, yielding 2 equivalents of $\mathrm{DPNH}$ oxidized for each fructose-1,6-diphosphate reacting. The system contained fructose-1,6-diphosphate, $5 \times 10^{-3} \mathrm{M}$; $\mathrm{DPNH}, 1.5 \times 10^{-4} \mathrm{M} ; \alpha$-glycerophosphate dehydrogenase, $0.01 \mathrm{mg}$; and triose isomerase, $0.01 \mathrm{mg}$. 2) The procedure of Taylor (17) in which the reaction is coupled with DPN-dependent 3-phosphoglyceraldehyde dehydrogenase ; 2 equivalents of DPNH are produced for each fructose-1,6-diphosphate reacting. The assay mixture contained fructose-1,6-diphosphate, $5 \times 10^{-3} \mathrm{M} ; \mathrm{DPN}, 1.5 \times$ $10^{-4} \mathrm{M}$; sodium arsenate, $1.7 \times 10^{-2} \mathrm{M}$; triose isomerase, $0.01 \mathrm{mg}$; and 3-phosphoglyceraldehyde dehydrogenase, 0.1 mg.

Triose isomerase was measured in the reaction, 3phosphoglyceraldehyde $\rightarrow$ dihydroxyacetone-phosphate, by coupling with DPNH-dependent $\alpha$-glycerophosphate dehydrogenase (18) in a system containing 3-phosphoglyceraldehyde, $3 \times 10^{-3} \mathrm{M}$ (D-isomer); $\mathrm{DPNH}, 1 \times 10^{-4}$ $\mathrm{M} ; \alpha$-glycerophosphate dehydrogenase, $0.01 \mathrm{mg}$. After addition of the enzyme to initiate the reaction, 2 minutes were allowed to elapse before absorbancy changes at 340 $\mathrm{m} \mu$ were measured.

The method for the measurement of 3-phosphoglyceraldehyde dehydrogenase was that of Velick (19). The assay mixture contained 3-phosphoglyceraldehyde, $2 \times 10^{-3}$ $\mathrm{M}$ (D-isomer); DPN, $1 \times 10^{-3} \mathrm{M}$; and sodium arsenate, $1.7 \times 10^{-2} \mathrm{M}$.

The method for the determination of phosphoglyceric kinase was that of Bücher (20), utilizing the reaction, 3 -phosphoglycerate $\rightarrow$ 1,3-diphosphoglycerate, and coupling with the reaction of DPNH-dependent 3-phosphoglyceraldehyde dehydrogenase. The assay system contained 3-phosphoglycerate, $5 \times 10^{-3} \mathrm{M}$; DPNH, $1.5 \times 10^{-4}$ $\mathrm{M} ; \mathrm{MgCl}_{2}, 1 \times 10^{-2} \mathrm{M}$; cysteine, $2 \times 10^{-2} \mathrm{M}$; ATP, $3 \times$ $10^{-3} \mathrm{M} ; 2,3$-diphosphoglycerate, $5 \times 10^{-3} \mathrm{M}$; and 3-phosphoglyceraldehyde dehydrogenase, $0.1 \mathrm{mg}$.

3-Phosphoglyceric mutase was determined as the limiting enzyme in the sequence, 3-phosphoglycerate $\rightarrow$ lactate. The assay system contained 3-phosphoglycerate, $5 \times 10^{-8} \mathrm{M} ; \mathrm{MgCl}_{2}, 3 \times 10^{-3} \mathrm{M} ; \mathrm{ADP}, 2 \times 10^{-3} \mathrm{M} ; \mathrm{DPNH}$, $1 \times 10^{-4} \mathrm{M}$; pyruvic kinase, $0.02 \mathrm{mg}$; lactic dehydrogenase, $0.05 \mathrm{mg}$; and enolase, $0.05 \mathrm{mg}$.

Enolase activity was measured as the limiting enzyme in the reaction, 2-phosphoglycerate $\rightarrow$ lactate, in a system containing 2-phosphoglycerate, $5 \times 10^{-3} \mathrm{M} ; \mathrm{MgCl}_{2}$, $3 \times 10^{-3} \mathrm{M}$; DPNH, $1.5 \times 10^{-4} \mathrm{M}$; ADP, $2 \times 10^{-3} \mathrm{M}$; pyruvic kinase, $0.05 \mathrm{mg}$; and lactic dehydrogenase, $0.05 \mathrm{mg}$.

Pyruvic kinase was assayed via the reaction, phosphoenolpyruvate $\rightarrow$ lactate, in a coupled system (21) containing phosphoenolpyruvate, $5 \times 10^{-3} \mathrm{M} ; \mathrm{MgCl}_{2}, 3 \times 10^{-3}$ $\mathrm{M}$; ADP, $2 \times 10^{-3} \mathrm{M}$; DPNH, $1 \times 10^{-4} \mathrm{M}$; and lactic dehydrogenase, $0.05 \mathrm{mg}$.

The method for the measurement of lactic dehydrogenase was that of Kubowitz and Ott (22). The reaction 
TABLE I

Cofactor requirements for glycolysis in the hemolysate*

\begin{tabular}{|c|c|}
\hline $\begin{array}{l}\text { Component } \\
\text { omitted }\end{array}$ & $\begin{array}{c}\text { Lactate } \\
\text { production }\end{array}$ \\
\hline & 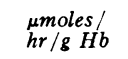 \\
\hline $\begin{array}{l}\text { None } \\
\text { Pi }_{\text {i }} \\
\text { DPN } \\
\text { ATP } \\
\text { Mg }^{++} \\
\text {DPN + ATP }\end{array}$ & $\begin{array}{r}21 \\
19 \\
8 \\
4 \\
2 \\
1\end{array}$ \\
\hline
\end{tabular}

* Reaction mixtures contained the following components in a total volume of $5 \mathrm{ml}: 30 \mu$ moles glucose, $5 \mu$ moles ATP, $1.5 \mu$ moles DPN, $7.5 \mu$ moles $\mathrm{MgCl}_{2}, 10 \mu$ moles of potassium phosphate ( $\mathrm{pH} 8.1$ ), and $2.0 \mathrm{ml}$ of hemolysate, previously adjusted to $\mathrm{pH} 8.1$ with glycine buffer. The mixtures were incubated for 1 hour at $37^{\circ} \mathrm{C}$, and lactate was determined on acid filtrates of the reaction mixtures. Glucose was omitted in the control reaction mixture.

mixture contained pyruvate, $2 \times 10^{-3} \mathrm{M}$; DPNH, $1 \times 10^{-4}$ $\mathrm{II}$; and $\mathrm{MgCl}_{2}, 3 \times 10^{-3} \mathrm{M}$.

Measurement of glycolysis in the intact cell. Suspensions of erythrocytes were used for the measurement of lactate production from glucose at a constant $\mathrm{pH}$. Adjustment of the $\mathrm{pH}$ of a red cell suspension to a desired value is difficult, owing to the necessity of overcoming the formidable buffering capacity of the cells without introducing a high salt concentration which would damage the cells. In the following method, which was found to be satisfactory, all operations were carried out at $4^{\circ} \mathrm{C}$, except where noted otherwise, and centrifugations were performed for 5 minutes at $1,800 \mathrm{G}$ in the International refrigerated centrifuge, model PR-2. After a preliminary centrifugation of the blood, the ACD-plasma and buffy coat were discarded, and the erythrocytes were treated by one of the procedures (A or B) described below.

A. $p H$ range 6.4 to 7.0 . The cells were washed by centrifugation with 2 vol of $0.15 \mathrm{M} \mathrm{KCl}$ and reconstituted to a hematocrit of 50 per cent in $0.08 \mathrm{M}$ potassium phosphate buffer; for cell suspensions having final $\mathrm{pH}$ values of $6.4,6.6,16.8$, and 7.0 , the $\mathrm{pH}$ of the phosphate buffer must be $6.0,6.3,6.6$, and 7.0 , respectively.

$B$. $p H 7.0$ to 9.4. For this $\mathrm{pH}$ range, washing of the cells and $\mathrm{pH}$ adjustment were carried out in a single operation, namely, by centrifugation of the cells in two volumes of $0.3 \mathrm{M}$ glycine buffer at a $\mathrm{pH} 0.7$ of a unit higher than the desired final $\mathrm{pH}$ of the cells. Prior to centrifugation, the cells suspended in the buffer were allowed to stand at room temperature for 10 minutes to insure complete $\mathrm{pH}$ equilibration. After the $\mathrm{pH}$ had been adjusted by this method, the cells were resuspended in an equal volume of $0.15 \mathrm{M} \mathrm{KCl}$.

Measurement of glycolysis in the hemolysate. Erythrocytes were washed once with 2 vol of $0.15 \mathrm{M} \mathrm{KCl}$, resuspended to a hematocrit of 33 per cent in $0.3 \mathrm{M}$ glycine buffer, 0.9 of a $\mathrm{pH}$ unit higher than the desired final $\mathrm{pH}$ of the hemolysate, and lysed by rapid freezing and

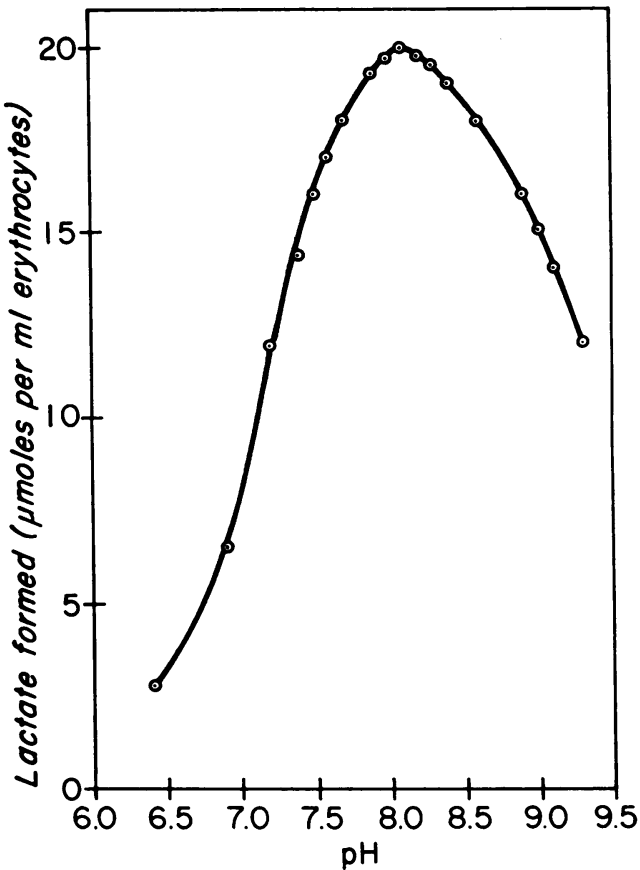

Fig. 1. Effect of PH on GLycolysis. Lactate formation was measured after a 3 -hour incubation at $37^{\circ} \mathrm{C}$ in a total volume of $6 \mathrm{ml}$, containing $70 \mu$ moles glucose, 15 $\mu$ moles $\mathrm{MgCl}_{2}, 180 \mu$ moles phosphate, and $2 \mathrm{ml}$ of red cells, adjusted to the indicated $\mathrm{pH}$ values as described in the Experimental section. The reaction was linear over the 3-hour incubation period, and the $\mathrm{pH}$ remained constant. Each point represents the average of 8 separate experiments.

thawing three times. The stromal fraction was not removed. When fortified with cofactors, the hemolysate preparation was used for the measurement of lactate production from glucose at a constant $\mathrm{pH}$.

\section{RESULTS}

Glycolysis in the intact cell. Although the conversion of glucose to lactate in the erythrocyte has been the subject of numerous investigations [e.g. (23-26)], most of the measurements have been carried out at $\mathrm{pH} 7.4$ or below. When a detailed examination is made of the effect of $\mathrm{pH}$ upon glycolysis, the $\mathrm{pH}$-activity curve is actually observed to be rather broad and the optimum falls at $\mathrm{pH} 8.1$ (Figure 1). At this $\mathrm{pH}$ optimum and with the optimal extracellular phosphate concentration of $0.03 \mathrm{M}$, the rate of lactate formation was 6.5 $\mu$ moles per hour per $\mathrm{ml}$ of cells. In the $\mathrm{pH}$ range 7.8 to 8.6 , the average value for the ratio of lactate production to glucose disappearance was 2.01 
TABLE II

Inhibition of glycolysis in the hemolysate*

\begin{tabular}{lc}
\hline Ion added & Lactate production \\
\hline & $\mu$ moles $/ h r / g ~ H b$ \\
None & 19 \\
$\mathrm{HPO}_{4}$ & 11 \\
$\mathrm{Na}^{+}$ & 12 \\
Tris $^{+}$ & 15
\end{tabular}

* The reaction mixtures contained in a total volume of 5 $\mathrm{ml}: 30 \mu$ moles glucose, $1.5 \mu$ moles DPN, $5 \mu$ moles ATP, $7.5 \mu$ moles $\mathrm{MgCl}_{2}, 1,500 \mu$ moles $\mathrm{HPO}_{4}{ }^{-}, \mathrm{Na}^{+}$, or Tris ${ }^{+}$ (where indicated), $1,000 \mu$ moles of glycine buffer ( $\mathrm{pH} \mathrm{8.1)}$, and $1.0 \mathrm{ml}$ of hemolysate. Incubations were carried out for 30 minutes at $37^{\circ} \mathrm{C}$, and lactate was determined on acid filtrates of the reaction mixtures.

(range, 1.82 to 2.18 for 8 separate experiments). No requirement for extracellular $\mathrm{Mg}^{++}$was noted. The system was inhibited approximately 23 per cent when the phosphate concentration was raised to $0.085 \mathrm{M}$.

Glycolysis in the hemolysate. Lysates prepared by repeated freezing and thawing of erythrocytes do not retain the capacity for carrying out the conversion of glucose to lactate. When fortified with $1 \times 10^{-3} \mathrm{M}$ ATP, $3 \times 10^{-4} \mathrm{M}$ DPN, $2 \times 10^{-3} \mathrm{M}$ $\mathrm{P}_{\mathrm{i}}$, and $1.5 \times 10^{-3} \mathrm{M} \mathrm{Mg}^{++}$, however, these preparations are fully reconstituted with respect to the original activity (Table I). The concentrations given above have been determined to be optimal for each cofactor. At levels higher than $10^{-3} \mathrm{M}$, ATP inhibits glycolysis in the reconstructed system. In addition, $\mathrm{Na}^{+}, \mathrm{HPO}_{4}{ }^{=}$, or Tris ${ }^{+}$, each at a concentration of $0.3 \mathrm{M}$, inhibits lactate production from glucose in this system (Table II). - Dialysis of the hemolysate against $0.1 \mathrm{M} \mathrm{KCl}$ for periods as short as 6 hours depressed the conversion of glucose to lactate by 20 per cent in the reconstructed system, and after 48 hours of dialysis, essentially all of the activity was lost.

In the reconstructed hemolysate system, the $\mathrm{pH}$ optimum for glycolysis was again 8.1, and the expected 1:2 stoichiometry was observed between glucose disappearance and lactate production, When the results in Table I are recalculated on the basis of intact cells- $0.33 \mathrm{~g}$ of hemoglobin being taken as the equivalent of $1 \mathrm{ml}$ of packed cells (27) $-6.9 \mu$ moles of lactate are produced per hour per $\mathrm{ml}$ of cells; this rate is comparable to that found in the intact cell. In terms of the over-all glycolytic sequence, therefore, the reconstructed hemolysate appears to be metabolically equivalent to the intact cell, and permits more flexibility in the design of experiments.

Measurement of the glycolytic enzymes. The preceding experiments define the over-all requirements for glycolysis in the intact erythrocyte and in the hemolysate. A study of the individual glycolytic enzymes was undertaken in order to examine specific steps in the glycolytic sequence and to obtain information necessary for understanding regulatory mechanisms in the erythrocyte.

The activities of the glycolytic enzymes in the hemolysate were measured by the procedures described in the Experimental section, and the results are summarized in Table III; each value represents the average of at least four separate experiments. Since the over-all glycolytic rate in the red cell is maximal at $\mathrm{pH} 8.1$, the individual activities were measured arbitrarily at that $\mathrm{pH}$.

TABLE III

Levels of glycolytic enzymes in the hemolysate

\begin{tabular}{lccl}
\hline \hline \multicolumn{1}{c}{ Enzyme } & $\begin{array}{c}\text { Data from } \\
\text { present } \\
\text { investigation }\end{array}$ & Other data & References \\
\hline Hexokinase & $\mu$ moles substrate converted $/ \mathrm{hr} / \mathrm{ml} R B C$ & \\
Phosphoglucose isomerase & 10 & $6,6,21$ & $(26),(28),(29)$ \\
Phosphofructokinase & 151 & $150,630,990$ & $(30),(31),(32)$ \\
Aldolase & 82 & 33,97 & $(33),(29)$ \\
Triose isomerase & 31 & 24,39 & $(34),(35)$ \\
Phosphoglyceraldehyde & 5,100 & 4,437 & $(36)$ \\
dehydrogenase & 800 & $249,1,083$ & $(36),(29)$ \\
Phosphoglyceric kinase & 1,910 & 1,580 & $(29)$ \\
Phosphoglyceric mutase & 228 & 351 & $(37),(36)$ \\
Enolase & 95 & 103 & $(29)$ \\
Pyruvic kinase & 158 & 179 & $(38),(34),(29)$ \\
Lactic dehydrogenase & 1,257 & $2,670,1,140,932$ & \\
\hline
\end{tabular}


For comparison, other reported values for these activities are shown in the second column of the table. It should be noted, however, that many of the previous studies were carried out under conditions of temperature and $\mathrm{pH}$ which differed from those in the present investigation.

A lower value of $249 \mu$ moles per hour for 3-phosphoglyceraldehyde dehydrogenase was reported originally by Löhr and Waller (36), but this has now been superseded (29) by a value of $1,083 \mu$ moles per hour, which agrees more closely with our value of 800 . On the other hand, no explanation can be given for the fact that our value of $151 \mu$ moles per hour for phosphoglucose isomerase, which was determined by three different assays (see Experimental section), is low relative to most of the other reported values $(31,32)$.

Mention should be made of a difficulty encountered in the assay of phosphoglyceric kinase. When this enzyme is assayed by following Reaction 2 in the forward direction (20) (see diagram, below), the substrate, 1,3-diphosphoglycerate, is generated via Reaction 1 by admixing 3-phosphoglyceraldehyde, $\mathrm{P}_{\mathbf{i}}$, and DPN with excess 3 -phosphoglyceraldehyde dehydrogenase. After the equilibrium in Reaction 1 is established, as indicated by the cessation of DPNH production, ADP and the preparation to be assayed for phosphoglyceric kinase are added. The production of additional DPNH is then used to follow the rate of Reaction 2.

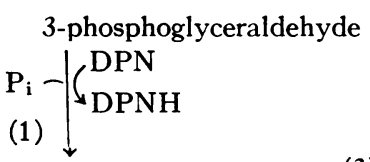

The occurrence of 2,3-diphosphoglyceric mutase (Reaction 3) interferes with the assay for phosphoglyceric kinase, since it removes 1,3-diphosphoglycerate. The side reaction can be repressed, however, by the addition of excess 2,3-diphosphoglycerate, which has been shown to be an inhibitor of the reaction (39). As indicated in Table IV, the amount of inorganic phosphate converted to various phosphate esters, via Reactions 1,2 , and
TABLE IV

\begin{tabular}{|c|c|}
\hline $\begin{array}{c}\text { 2,3-Diphosphoglycerate } \\
\text { added }\end{array}$ & $\begin{array}{l}\text { Pi converted to } \\
\text { phosphate esters }\end{array}$ \\
\hline umoles & mumoles \\
\hline $\begin{array}{r}0 \\
5 \\
10\end{array}$ & $\begin{array}{l}65 \\
33 \\
34\end{array}$ \\
\hline
\end{tabular}

* Phosphoglyceric kinase was measured in the forward reaction $(20)$ at $25^{\circ} \mathrm{C}$, in a cuvet in which the total volume of the assay system was $1.0 \mathrm{ml}$, containing: $0.4 \mu \mathrm{mole}$ D-3-phosphoglyceraldehyde; $10 \mu$ moles $\mathrm{KH}_{2} \mathrm{PO}_{4}, \mathrm{pH} 8.1$; $40 \mu$ moles $\mathrm{Na}_{2} \mathrm{HPO}_{4}, \mathrm{pH} 8.1 ; 0.1 \mu$ mole DPN ; $5 \mu$ moles $\mathrm{MgCl}_{2} ; 0.01 \mathrm{mg}$ of 3-phosphoglyceraldehyde dehydrogenase; 2,3-diphosphoglycerate as indicated; and an aliquot of hemolysate equivalent to $0.014 \mathrm{mg}$ of hemoglobin. In the course of an assay, the absorbancy at $340 \mathrm{~m} \mu$ of a mixture of all the components, except hemolysate and ADP, was measured until it remained constant, at which time the hemolysate and $0.5 \mu$ mole of ADP were added. The increase in absorbancy at $340 \mathrm{~m} \mu$ was then measured over a period of 5 minutes, and the amount of $P_{i}$ converted to phosphate esters was calculated from the equations given by Bücher (20).

3 , is reduced to a constant level as the amount of 2,3-diphosphoglycerate is increased. Although erythrocytes contain large quantities of 2,3-diphosphoglycerate (40), the amount of hemolysate added to the assay system is so small that $5 \mu$ moles of exogenous 2,3-diphosphoglycerate must be supplied in order to study the kinase reaction in either direction.

\section{DISCUSSION}

The over-all glycolytic rate in the intact erythrocyte was found to be independent of extracellular $\mathrm{Mg}^{++}$, indicating that a sufficient amount of this ion is available within the cell to meet the needs of the $\mathrm{Mg}^{++}$-requiring enzymes in this pathway. In the hemolysate system, however, a definite requirement emerges for added $\mathrm{Mg}^{++}$. On the other hand, although there is a requirement for extracellular inorganic phosphate (optimal level, 0.03 M) for glycolysis in the intact cell, the addition of phosphate to the hemolysate system does not appreciably affect the glycolytic rate. It is possible that adenosine triphosphatase and other phosphatases, "activated" by the lytic procedure, produce a continuous supply of inorganic phosphate by the breakdown of phosphate esters.

At concentrations higher than $0.03 \mathrm{M}$, phosphate inhibits glycolysis in the intact cell. This effect can be localized between glucose and 3-phospho- 
glyceraldehyde, since the conversion of glucose to lactate and of inosine to lactate involves a common pathway at the triose phosphate level, and since the latter sequence is stimulated rather than inhibited by high $(>0.03 \mathrm{M})$ concentrations of phosphate (unpublished results, this laboratory). Phosphate inhibition of glycolysis in erythrocytes is likely to occur in cells stored for long periods of time in ACD, since under these conditions inorganic phosphate accumulates due to the breakdown of ATP and 2,3-diphosphoglycerate (41).

The $\mathrm{pH}$ optimum (8.1) for erythrocyte glycolysis is approximately the same as that observed for hexokinase in the red cell (42). The experimentally determined ratio of lactate production to glucose disappearance is 2 in the presence of excess glucose, which would follow if the first step in the sequence (i.e., glucose $\rightarrow$ glucose-6-phosphate) were rate limiting. If hexokinase is located at the cell surface, and if the phosphorylation of glucose is a rate-limiting step, it would not be surprising to find that the $\mathrm{pH}$ requirement for hexokinase would largely determine the $\mathrm{pH}$ at which the over-all rate is maximal.

In the present investigation the activity of each of the glycolytic enzymes in the erythrocyte has been determined. In general, the enzyme levels in Table III may be grouped into three categories: $1)$ the low activities ( $<85 \mu$ moles per hour) represented by hexokinase, phosphofructokinase, and aldolase; 2) the intermediate values (100 to 300 $\mu$ moles per hour) of phosphoglucose isomerase, phosphoglyceric mutase, enolase, and pyruvic kinase; and 3) the high values ( $>800 \mu$ moles per hour) of triose isomerase, 3-phosphoglyceraldehyde dehydrogenase, phosphoglyceric kinase, and lactic dehydrogenase. Thus, the enzymes which catalyze the ATP-dependent reactions, hexokinase and phosphofructokinase, are in the lowest category, and hence potentially rate limiting, while the enzymes involved in ATP-regeneration (phosphoglyceric kinase and pyruvic kinase) are both present at much greater levels. Comparable findings have been reported for other predominantly glycolyzing systems, such as ascites tumor cells and HeLa cells (43) and chicken erythrocytes (44).

The levels of the glycolytic enzymes can be correlated, in part, with the observed steady-state levels of various phosphorylated intermediates of glycolysis. Column chromatography by Bartlett (45) has shown that, with the exception of 2,3-diphosphoglycerate (which is present in abnormally high quantities in the red cell), glucose-6phosphate, fructose-6-phosphate, fructose-1,6-diphosphate, and monophosphoglycerate are the only glycolytic intermediates which accumulate in measurable quantities. Since the accumulation of an intermediate, $\mathrm{B}$, can result from conditions where $\mathrm{A} \stackrel{\text { fast }}{\longrightarrow} \mathrm{B} \stackrel{\text { slow }}{\longrightarrow} \mathrm{C}$, it would follow that only those phosphate esters will accumulate which are substrates for the enzymatic reactions having a low activity. This correlation is seen from the data in Table III, since phosphoglucose isomerase, phosphofructokinase, aldolase, and enolase are, in fact, low in activity. It should be noted, however, that the rate of hexokinase is lower than that of either phosphoglucose isomerase or glucose-6phosphate dehydrogenase and, according to the above argument, glucose-6-phosphate would not be expected to accumulate if only these factors were involved. There may be another route leading to the formation of glucose-6-phosphate, perhaps from glycogen or a pentose phosphate, which contributes to the observed steady-state level of glucose-6-phosphate.

Even when tested under the favorable conditions of a single-step assay, the hexokinase-controlled reaction ( $10 \mu$ moles of glucose converted per hour per $\mathrm{ml}$ of cells) is rate limiting in the sequence. This value may be compared to the over-all glycolytic rate in the intact cell, or in a suitably reconstructed hemolysate, in which 6.5 $\mu$ moles of lactate are produced per hour per $\mathrm{ml}$ of cells; this corresponds to an over-all metabolic rate of $3.25 \mu$ moles with respect to glucose utilization. No explanation can be offered for the observation that certain other enzymes in the sequence are present at levels several orders of magnitude higher than that of the apparent pacemaker enzyme, hexokinase.

Regulation of erythrocyte glycolysis may be examined in terms of the steady-state levels of ATP ( $1 \mu$ mole per ml of cells $)$, ADP $(0.2 \mu$ mole $)$, and inorganic phosphate $(0.4 \mu \mathrm{mole})(45)$. Since glycolysis involves the net disappearance of both ADP and inorganic phosphate, with the concomitant production of ATP, it is evident that the availability of ADP may be a rate-limiting factor. In 
order to sustain an over-all rate of about $3 \mu$ moles of glucose utilized per hour, a minimal rate of ATP breakdown to ADP and inorganic phosphate of about $6 \mu$ moles per hour would be necessary. There are two ways in which this could be accomplished: 1) by the action of adenosine triphosphatase ; and 2) as a consequence of ATP-dependent synthetic reactions in which $\mathrm{ADP}$ and inorganic phosphate are products. It is difficult to assess the magnitude of the latter contribution, but previous studies from this laboratory (46) have shown that the level of adenosine triphosphatase in hemolysates is about $4 \mu$ moles of ATP broken down per hour. This effect, by itself, would almost maintain glycolysis, provided that it occurs at that rate within the intact cell.

The conversion of glucose to lactate in the erythrocyte normally proceeds almost entirely via the glycolytic scheme rather than by the hexose monophosphate shunt and pentose cycle (23). Comparison of the levels of phosphoglucose isomerase (151 $\mu$ moles of substrate converted per hour) and glucose-6-phosphate dehydrogenase $(74 \mu$ moles per hour) does not reveal why glycolysis should predominate, although the higher level of phosphoglucose isomerase plus the sluggishness of the erythrocyte in reoxidizing TPNH may result in the diversion of most of the glucose-6-phosphate toward fructose-6-phosphate rather than to 6-phosphogluconate.

\section{SUM MARY}

1. A method is described for the preparation of erythrocyte suspensions in which the inherent $\mathrm{pH}$ of the cells may be adjusted to any desired value in the region of 6.4 to 9.4 ; the $\mathrm{pH}$ is maintained during glycolysis for a period of 3 hours at $37^{\circ} \mathrm{C}$. In the intact cell, maximal production of lactate ( 6.5 $\mu$ moles per hour per $\mathrm{ml}$ of red cells) from glucose was achieved at $\mathrm{pH} 8.1$, with an extracellular concentration of inorganic phosphate of $0.03 \mathrm{M}$.

2. When glycolysis is reconstructed in a hemolysate system fortified with ATP, DPN, inorganic phosphate, and $\mathrm{Mg}^{++}$, the $\mathrm{pH}$ optimum and the rate of lactate production are the same as those observed for the intact erythrocyte. Lactate production in the hemolysate is inhibited by $\mathrm{Na}^{+}$, $\mathrm{HPO}_{4}{ }^{=}$, and Tris.

3 . The levels of the individual glycolytic enzymes have been determined in the hemolysate at $\mathrm{pH} 8.1$.
These findings are discussed with reference to the over-all glycolytic rate and are correlated with the steady-state levels in the cell of ADP, ATP, inorganic phosphate, and phosphorylated intermediates of glycolysis.

\section{REFERENCES}

1. Chapman, R. G., Huennekens, F. M., and Gabrio, B. W. The control of erythrocyte metabolism by pH. Clin. Res. 1960, 8, 127.

2. Barker, S. B. Preparation and colorimetric determination of lactic acid in Methods in Enzymology, S. P. Colowick and N. O. Kaplan, Eds. New York, Academic Press, 1957, vol. 3, p. 241.

3. Evelyn, K. A., and Malloy, H. T. Microdetermination of oxyhemoglobin, methemoglobin, and sulfhemoglobin in a single sample of blood. J. biol. Chem. 1938, 126, 655.

4. Horn, H. D., and Bruns, F. H. Quantitativ Bestimmung von $\mathrm{L}(+)$-Milchsäure mit Milchsäuredehydrogenase. Biochim. biophys. Acta 1956, 21, 378.

5. Saifer, A., and Gerstenfeld, S. The photometric microdetermination of blood glucose with glucose oxidase. J. Lab. clin. Med. 1958, 51, 448.

6. Gabrio, B. W., and Finch, C. A. Erythrocyte preservation. I. The relation of the storage lesion to in vivo erythrocyte senescence. J. clin. Invest. 1954, 33, 242.

7. Chase, A. M. The measurement of luciferin and luciferase. V. Applications of bioluminescent systems. I. Applications based on firefly luminescent system in Methods in Biochemical Analysis, D. Glick, Ed. New York, Interscience Publishers, 1960 , vol. 8 , p. 111.

8. Strehler, B. L., and McElroy, W. D. Assay of adenosine triphosphate in Methods in Enzymology, S. P. Colowick and N. O. Kaplan, Eds. New York, Academic Press, 1957, vol. 3, p. 871.

9. Kornberg, A., and Pricer, W. E., Jr. Enzymatic phosphorylation of adenosine and 2,6-diaminopurine riboside. J. biol. Chem. 1951, 193, 481.

10. Roe, J. H. A colorimetric method for the determination of fructose in blood and urine. J. biol. Chem. 1934, 107, 15.

11. Bartlett, G. R. Methods for the isolation of glycolytic intermediates by column chromatography with ion exchange resins. J. biol. Chem. 1959, 234, 459.

12. Dische, Z., and Borenfreund, E. A new spectrophotometric method for the detection and determination of keto sugars and trioses. J. biol. Chem. 1951, 192, 583.

13. Kornberg, A., and Horecker, B. L. Glucose-6-phosphate dehydrogenase in Methods in Enzymology, S. P. Colowick and N. O. Kaplan, Eds. New York, Academic Press, 1955, vol. 1, p. 323.

14. Srere, P., Cooper, J. R., Tabachnick, M., and Racker, E. The oxidative pentose phosphate cycle. I. 
Preparation of substrates and enzymes. Arch. Biochem. 1958, 74, 295.

15. Ling, K., Byrne, W. L., and Lardy, H. Phosphohexokinase in Methods in Enzymology, S. P. Colowick and N. O. Kaplan, Eds. New York, Academic Press, 1955, vol. 1, p. 306.

16. $\mathrm{Wu}, \mathrm{R}$., and Racker, E. Regulatory mechanisms in carbohydrate metabolism. III. Limiting factors in glycolysis of ascites tumor cells. J. biol. Chem. 1959, 234, 1029.

17. Taylor, J. F. Aldolase from muscle in Methods in Enzymology, S. P. Colowick and N. O. Kaplan, Eds. New York, Academic Press, 1955, vol. 1, p. 310 .

18. Meyer-Arendt, E., Beisenherz, G., and Bücher, T. Isolierung der Triosephosphat-isomerase. Naturwissenschaften 1953, 40, 59.

19. Velick, S. F. Glyceraldehyde-3-phosphate dehydrogenase from muscle in Methods in Enzymology, S. P. Colowick and N. O. Kaplan, Eds. New York, Academic Press, 1955, vol. 1, p. 401.

20. Bücher, T. Phosphoglycerate kinase from Brewer's yeast in Methods in Enzymology, S. P. Colowick and N. O. Kaplan, Eds. New York, Academic Press, 1955, vol. 1, p. 415.

21. Bücher, T., and Pfleiderer, G. Pyruvate kinase from muscle in Methods in Enzymology, S. P. Colowick and N. O. Kaplan, Eds. New York, Academic Press, 1955, vol. 1, p. 435.

22. Kubowitz, F., and Ott, P. Isolierung und Kristallisation eines Gärungsfermentes aus Tumoren. Biochem. Z. 1943, 314, 94.

23. Murphy, J. R. Erythrocyte metabolism. II. Glucose metabolism and pathways. J. Lab. clin. Med. 1960, 55, 286.

24. Rapoport, S. Dimensional, osmotic, and chemical changes of erythrocytes in stored blood. I. Blood preserved in sodium citrate, neutral and acid citrate-glucose (ACD) mixtures. J: clin. Invest. 1947, 26, 591.

25. Bartlett, G. R., and Marlowe, A. A. Comparative effects of the different formed elements on normal human blood glycolysis. J. appl. Physiol. 1953, 6, 335.

26. Kashket, S., Rubinstein, D., and Denstedt, O. F. Studies on the preservation of blood. V. The influence of the hydrogen ion concentration on certain changes in blood during storage. Canad. J. Biochem. 1957, 35, 827.

27. Osgood, E. E. Normal hematologic standards. Arch. intern. Med. 1935, 56, 849.

28. Bartlett, G. R. Enzyme systems in the red blood cell. Bull. Scripps Metabolic Clin. 1951, 2, 1.

29. Löhr, G. W., and Waller, H. D. Biochemie und Pathogenese der enzymopenischen hämolytischen Anämien. Dtsch. med. Wschr. 1961, 86, 27.
30. Tsuboi, K. K., Estrada, J., and Hudson, P. B. Enzymes of the human erythrocyte IV. Phosphoglucose isomerase, purification and properties. J. biol. Chem. 1958, 231, 19.

31. Bodansky, O. Serum phosphohexose isomerase in cancer. Method of determination and establishment of range of normal values. Cancer 1954, 7, 1191.

32. Bruns, F. H., and Vahlhaus, E. Phosphoriboisomerase und Phosphohexoseisomerase in Serum, roten Blutzellen und Geweben. Naturwissenschaften 1956, 43, 180.

33. Brownstone, Y. S., and Blanchaer, M. C. Effect of adenosine on phosphofructokinase activity of preserved blood. Amer. J. Physiol. 1957, 189, 105.

34. Heller, P., Weinstein, H. G., West, M., and Zimmerman, H. J. Glycolytic, citric acid cycle, and hexosemonophosphate shunt enzymes of plasma and erythrocytes in megaloblastic anemia. J. Lab. clin. Med. 1960, 55, 425.

35. Bruns, F. Über die Aldolase der Erythrocyten. Biochem. Z. 1954, 325, 429

36. Löhr, G. W., and Waller, H. D. Zellstoffwechsel und Zellalterung. Klin. Wschr. 1959, 37, 833.

37. Bock, H. E., Karges, O., Löhr, G. W., and Waller, H. D. Fermenteigenschaften roten Blutzellen bei Lebererkrankungen. Klin. Wschr. 1958, 36, 56.

38. Birkbeck, J. A., and Stewart, A. G. The estimation of lactate dehydrogenase activity of human erythrocytes. Canad. J. Biochem. 1961, 39, 257.

39. Rapoport, S., and Luebering, J. An optical study of diphosphoglycerate mutase. J. biol. Chem. 1952, 196, 583.

40. Gabrio, B. W., Finch, C. A., and Huennekens, F. M. Erythrocyte preservation: A topic in molecular biochemistry. Blood 1956, 11, 103.

41. Gabrio, B. W., Hennessey, M., Thomasson, J., and Finch, C. A. Erythrocyte preservation. IV. In vitro reversibility of the storage lesion. J. biol. Chem. 1955, 215, 357.

42. Rapoport, S., Hinterberger, U., and Hofmann, E. C. G. Die begrenzende Rolle der Hexokinase-Reaktion für die anaerobe Glykolyse der roten Blutzellen. Naturwissenschaften 1961, 48, 501.

43. Racker, E., Wu, R., and Alpers, J. B. Carbohydrate metabolism in ascites tumor and $\mathrm{HeLa}$ cells in Amino Acids, Proteins, and Cancer Biochemistry, J. T. Edsall, Ed. New York, Academic Press, 1960, p. 175.

44. Wu, R., and Racker, E. Unpublished observations.

45. Bartlett, G. R. Human red cell glycolytic intermediates. J. biol. Chem. 1959, 234, 449.

46. Caffrey, R. W., Tremblay, R., Gabrio, B. W., and Huennekens, F. M. Erythrocyte metabolism. II. Adenosinetriphosphatase. J. biol. Chem. 1956, 223, 1. 